\title{
Characterization of all Surgical Specimens Provided by a Portuguese Department of Ophthalmology over a 13 Year Period
}

\section{Caracterização de todas as Amostras Biológicas Colhidas num Serviço de Oftalmologia Português durante 13 Anos de Atividade}

José FERREIRA MENDES $\square^{1}$, Ana Margarida FERREIRA ${ }^{2}$, Cristina FREITAS ${ }^{1}$

Acta Med Port 2017 Nov;30(11):805-812 - https://doi.org/10.20344/amp.8614

\section{ABSTRACT}

Introduction: We intend to evaluate clinically, topographically and morphologically all surgical specimens sent by the Department of Ophthalmology of Hospital de Braga to the Department of Pathology of the same hospital.

Material and Methods: Two hundred and fifty eight surgically obtained specimens, from the Department of Ophthalmology of Hospital de Braga, analyzed in the Department of Pathology, from January 2002 to June 2015, were characterized. Data was arranged according to year, age, sex, topography and morphological diagnosis according to the SNOMED ${ }^{\circledR}$ coding system.

Results: Mean age at time of diagnosis was 54.6 years old; $52.3 \%$ were male subjects. The number of specimens was relatively stable until the year 2010, with a significant increase between 2011 and 2013. Most specimens sent corresponded to eyelid (54.7\%), followed by conjunctiva $(26.7 \%)$; the most common pathological diagnosis was malignant epithelial lesions $(22.48 \%)$, followed by melanocytic tumours (22.09\%) and benign epithelial lesions (17.05\%).

Discussion: The results are distinct from previous publications presumably because of differences between the populations submitted to analysis.

Conclusion: This is the first indexed publication characterizing surgical specimens from a Department of Ophthalmology in Portugal; moreover, it also includes an extensive review of global epidemiological data about ophthalmic surgical specimens.

Keywords: Eye/pathology; Eye Diseases/surgery; Eye Enucleation

\section{RESUMO}

Introdução: Pretende-se avaliar clínica, topográfica e morfologicamente todos as amostras biológicas enviadas pelo Serviço de Oftalmologia do Hospital de Braga para o Serviço de Anatomia Patológica do mesmo Hospital.

Material e Métodos: Duzentas e cinquenta e oito amostras biológicas obtidas cirurgicamente pelo Serviço de Oftalmologia do Hospital de Braga e analisadas pelo Serviço de Anatomia Patológica (Hospital de Braga), no período de janeiro de 2002 a junho de 2015 . Os dados foram organizados de acordo com o ano, idade, sexo, topografia e diagnóstico patológico de acordo com sistema de codificação SNOMED ${ }^{\circledR}$.

Resultados: A idade média dos doentes à altura do diagnóstico foi de 54,6 anos, sendo $52,3 \%$ destes indivíduos do sexo masculino. 0 número de amostras oscilou pouco até ao ano 2010, verificando-se um aumento importante entre 2011 e 2013. A maioria das amostras biológicas enviadas foi de pele de pálpebra $(54,7 \%)$, seguida de conjuntiva $(26,7 \%)$; os diagnósticos morfológicos mais comuns foram as lesões epiteliais malignas (22,48\%), seguido pelos tumores melanocíticos (22,09\%) e as lesões epiteliais benignas (17,05\%).

Discussão: Os resultados são distintos das publicações anteriores, presumivelmente devido a diferenças entre as populações analisadas.

Conclusão: Esta é a primeira publicação indexada caracterizando as amostras biológicas de um Serviço de Oftalmologia em Portugal; além disso, inclui uma extensa revisão de dados epidemiológicos sobre amostras biológicas oftalmológicas a nível global.

Palavras-chave: Enucleação Ocular; Oftalmopatias/cirurgia; Olho/patologia

\section{INTRODUCTION}

Data regarding the diagnosis coming from ophthalmic surgical specimens has been published for a long time. In 1998, Spraul et al' reported a retrospective long term (55 years) and large (24 444 specimens) study, providing relative frequencies of specimens submitted to a Department of Pathology that exclusively evaluated these ophthalmic specimens. After this, many consecutive large studies have been published accounting relative frequencies of morphological diagnosis and/or histological examination of specific tissues; however, none of them have analysed all the ophthalmic surgical specimens obtained by a single Department of Ophthalmology.

The aim of this study is to characterize all the ophthalmic surgical specimens examined by the Department of Pathology of the same hospital over a period of 13 years.

\section{MATERIAL AND METHODS}

In this study, everlasting cases of specimens submitted from the Department of Ophthalmology of Hospital de Braga to the Department of Pathology are reported, corresponding to the period between January 2002 and June 2015. Year of surgery, year of diagnosis, age, sex and

\footnotetext{
1. Department of Ophthalmology. Hospital de Braga. Braga. Portugal.

2. Department of Pathology. Hospital de Braga. Braga. Portugal.

$\triangle$ Autor correspondente: José Ferreira Mendes. jcfmendes88@gmail.com

Recebido: 29 de dezembro de 2016 - Aceite: 07 de agosto de 2017| Copyright @ Ordem dos Médicos 2017
} 
SNOMED ${ }^{\circledast}$ topography and diagnostic codes for ophthalmic pathology of all specimens were introduced in a database. No phacoemulsification or vitrectomy fluid aspirations were evaluated. All specimens were histologically analysed with light microscopy.

\section{RESULTS}

Two hundred and fifty eight cases were reviewed, corresponding to a period of 12.5 years (150 months), from January 2002 to June 2015. The number of specimens, which had been stable until 2010, increased between the 2011 and 2013, remaining stable until today (Fig. 1).

Age and sex were recorded in all cases. Ages ranged from eight months old to 97.4 years old, and its distribution is shown in Fig. 2; mean age was 54.6 years old and its standard deviation was 24.5 years old. There were 135 $(52.3 \%)$ males and 123 females (47.7\%); all of them caucasians.

The relative frequency of topographic locations with histologic diagnosis is presented in Fig. 3 . The most common was eyelid $(n=141)$, followed by conjunctiva ( $n$ $=69)$, orbit $(n=23)$, enucleation $(n=13)$, cornea $(n=5)$, lacrimal gland $(n=3)$, caruncula $(n=2)$ and other (ciliary body and choroid, $n=2$ ).

Eyelid specimens were the most common (Table 1).
Mean age was 60.7 years old and female gender was the most affected $(n=79 ; 56.03 \%)$. Malignant epithelial lesions comprised the most frequent lesions.

The second tissue most commonly analysed was conjunctiva (Table 2). Mean age was 46,1 year-old, and male gender was the commonest $(n=44 ; 63.7 \%)$. Melanocytic tumours were the most frequent diagnosis.

The orbit was the third most common specimen (Table 3 ). Mean age was 40.7 years old and male was the most common gender $(n=12 ; 52.2 \%)$. Benign epithelial lesions were the most frequent diagnosis.

The fourth most common specimen were enucleated eyes (Table 4). Mean age was 52.5 years old and male was the most frequent gender $(n=11 ; 84.6 \%)$. Melanoma was the most frequent diagnosis.

Cornea was only the fifth most common tissue, accounting for 5 cases (Table 5). Mean age was 54.6 year-old, and female gender $(n=3 ; 66.7 \%)$ was the most affected. All specimens were obtained immediately after trauma events.

Lacrimal gland was the sixth most frequent location of specimens (Table 6). Female gender was predominant (n $=2 ; 66.7 \%$ ). Mean age was 73 years old. Two cases were diagnosed as benign epithelial tumours. The other was a follicular lymphoma.

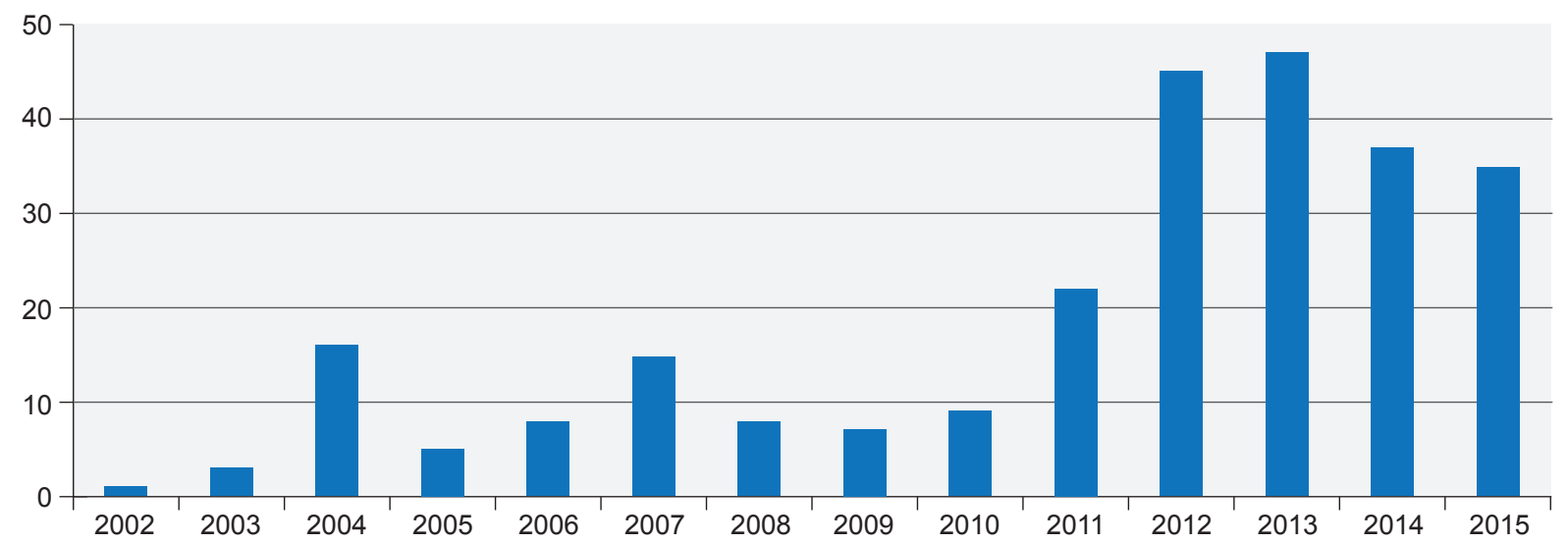

Figure 1 - Number of specimens distributed by year

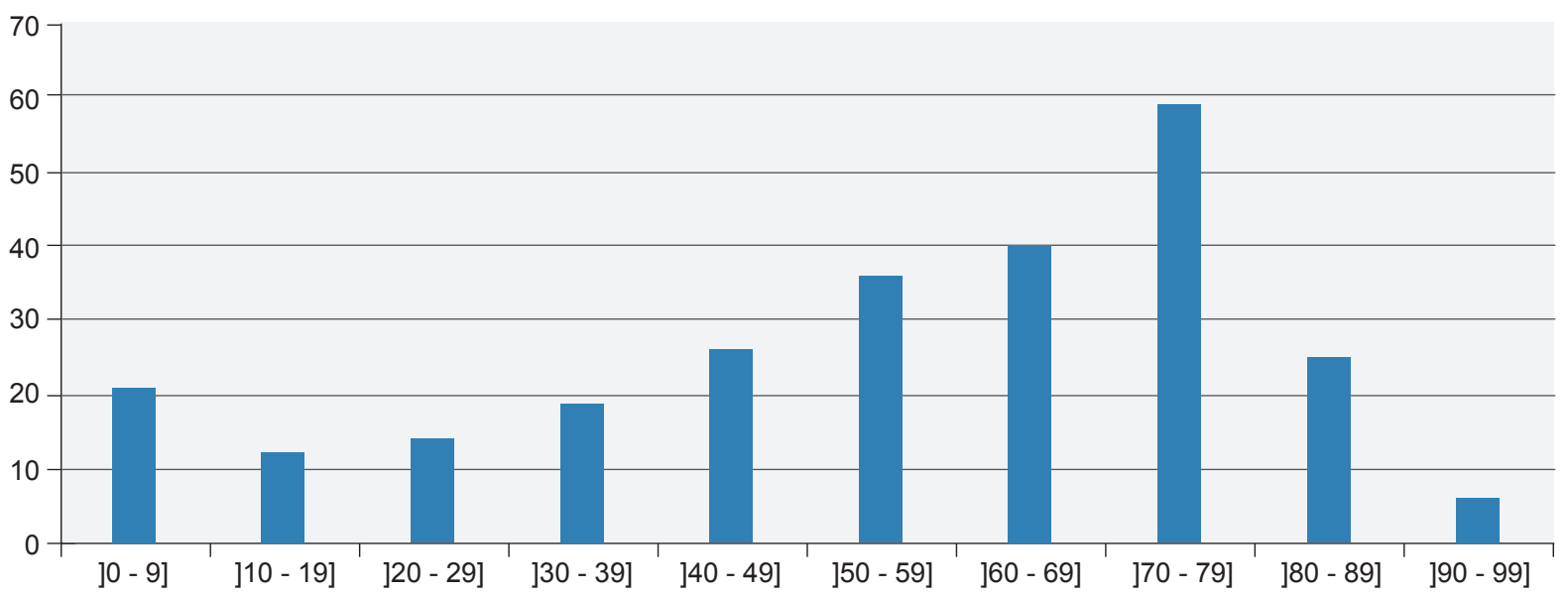

Figure 2 - Distribution of specimens by patients' age 
Enucleation

Caruncula

Eyelid

Lacrimal gland

Cornea

Conjunctiva

Orbit

Other

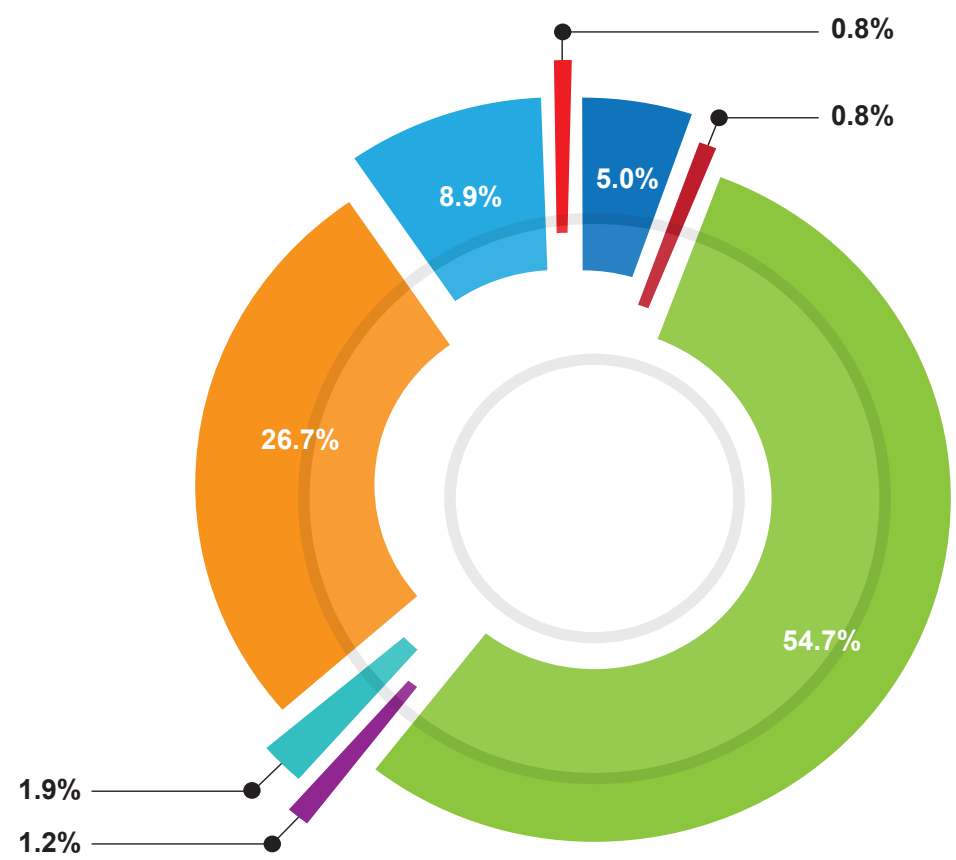

Figure 3 - Relative frequency of topographic locations of specimens

Caruncula was the less frequent topography, accounting only for two cases, in males (Table 7). Mean age was 44 years old. The first case was a benign epithelial lesion and second was a melanocytic tumour.

\section{DISCUSSION}

The Department of Pathology of Hospital de Braga was founded only in 1990 and received its first ophthalmic specimen in January 2002. Municipal investment, local medical school and, more importantly, updates in local health policy, turned Hospital de Braga into a tertiary center for many specialities since 2009 , assisting more than 1,2 million people today.

We retrospectively studied all specimens obtained by the Department of Ophthalmology of Hospital de Braga, which were evaluated by the Department of Pathology of the same hospital. There was no specimen analysed outside this institution. All specimens were obtained in surgeries exclusively performed by ophthalmologists.

The number of specimens analysed over 13 years must be divided in three periods. From 2002 to 2010 , the average number of specimens was eight per year, according to the level of differentiation, smaller number of physicians and target population. Between 2011 and 2013, specimens significantly increased to 38 per year, as national health policies endorsed programs to reduce surgery waiting lists. The number of consultants for all kinds of ophthalmic subspecialties increased and the department was also selected for residency programs. Since 2014 to June 2015, a higher number of specimens - average of four specimens per month / overall average of 48 per year - have been analysed.

Specimens from the eyelid were the most frequent. This is significantly different from the only study found reporting the largest number of ophthalmic specimens. In Spraul's study, cornea was the most common topographic area (39.3\%); eyelid was only the fifth $(8.0 \%) .{ }^{1}$ In this study, no characterization was made regarding location (for example, upper or lower eyelid). Malignant epithelial tumours were the most common diagnosis, accounting for $36.17 \%$ cases while only $17.0 \%$ in Spraul's study. Basal cell carcinoma was the most common subtype, with $88.24 \%$ of cases; in the remaining literature, we found this to range from $14.3 \%$ to $86 \% .^{2-9}$ The mean age for malignant epithelial tumours (74.6 years old) was different from other publications. ${ }^{7-8}$ Melanocytic tumours (21.99\%) and benign epithelial lesions $(21.28 \%)$ were the second and the third commonest diagnoses. In the study by Deprez, melanocytic and benign epithelial lesions were all considered as 'benign tumours', and accounted for $84 \%$ of specimens, and 'malignant tumours' accounted for $16 \%{ }^{3}$

Conjunctiva was the second most frequent topography $(26.7 \%)$. Like the eyelid, it is significantly different from Spraul's study (7.7\%)..$^{1}$ In this study, melanocytic tumours were the most common, accounting for $36.23 \%$ of cases, followed by miscellaneous tumours (14.49\%), inflammation (11.59\%) and malignant epithelial lesions (10.14\%). These results are different from some previous important reports: in some, inflammatory, acquired epithelial and degenerative lesions were the most common. ${ }^{10}$ Compound nevi were the commonest conjunctival nevi subtype in Alkatan study, such as in this. ${ }^{11}$ Shield, a world reference in conjunctiva, claims that squamous cell carcinoma is one of the most frequent non-melanocytic neoplastic lesions, which have an important incidence in our study. ${ }^{12}$ Also, his results concerning conjunctiva lesions from children were also similar to our study. ${ }^{13}$ In a quarter of cases, the pathological diagnoses were different from the clinical diagnosis, making 
Table 1 - Frequency of specimens from eyelid

\begin{tabular}{|c|c|c|c|}
\hline Eyelid & Number & $\%$ & Mean age \\
\hline Miscellaneous lesions & 7 & $4.96 \%$ & 64 \\
\hline Cutaneous calcinosis & 1 & $14.29 \%$ & 79 \\
\hline Fibrosis & 3 & $42.86 \%$ & 65.33 \\
\hline Other & 3 & $42.86 \%$ & 57.67 \\
\hline Inflammation & 9 & $6.38 \%$ & 49.44 \\
\hline Chronic inflammation, unspecific & 8 & $88.89 \%$ & 53.75 \\
\hline Granulation tissue proliferation & 1 & $11.11 \%$ & 15 \\
\hline Infeccious diseases & 3 & $2.13 \%$ & 18.33 \\
\hline Molluscum contagiosum & 1 & $33.33 \%$ & 6 \\
\hline Wart & 2 & $66.67 \%$ & 24.5 \\
\hline Benign epithelial tumours & 30 & $21.28 \%$ & 54.17 \\
\hline Epithelial cysts & 11 & $36.67 \%$ & 35.73 \\
\hline Squamous cell papilloma & 3 & $10.00 \%$ & 55 \\
\hline Hyperkeratosis & 1 & $3.33 \%$ & 40 \\
\hline Seborrheic keratosis & 12 & $40.00 \%$ & 70.33 \\
\hline Keratoacanthoma & 1 & $3.33 \%$ & 40 \\
\hline Hyperplasia & 2 & $6.67 \%$ & 71.5 \\
\hline Precancerous epithelial lesions & 2 & $1.42 \%$ & 81.5 \\
\hline Actinic keratosis & 2 & $100.00 \%$ & 81.5 \\
\hline Malignant epithelial lesions & 51 & $36.17 \%$ & 74.69 \\
\hline Basal cell carcinoma & 45 & $88.24 \%$ & 74.07 \\
\hline Squamous cell carcinoma & 6 & $11.76 \%$ & 79.33 \\
\hline Melanocytic tumours & 31 & $21.99 \%$ & 52.16 \\
\hline Blue nevus & 2 & $6.45 \%$ & 51.5 \\
\hline Juncional nevus & 2 & $6.45 \%$ & 38 \\
\hline Compound nevus & 8 & $25.81 \%$ & 51.63 \\
\hline Dermal nevus & 19 & $61.29 \%$ & 53.95 \\
\hline Tumours of the pilar structures of the eyelid & 1 & $0.71 \%$ & 9 \\
\hline Pilomatrixoma & 1 & $100.00 \%$ & 9 \\
\hline Vascular tumours & 6 & $4.26 \%$ & 51.83 \\
\hline Capillary hemangioma & 2 & $33.33 \%$ & 67.5 \\
\hline Cavernous hemangioma & 3 & $50.00 \%$ & 58.33 \\
\hline Hemangioendothelioma & 1 & $16.67 \%$ & 1 \\
\hline Lymphoid tumours and tumour-like conditions & 1 & $0.71 \%$ & 76 \\
\hline \multicolumn{4}{|l|}{ Lymphoma } \\
\hline Diffuse large B-cell lymphoma & 1 & $100.00 \%$ & 76 \\
\hline Total & 141 & & \\
\hline
\end{tabular}

it legitimate to recommend a systematic pathological

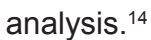

The orbit was the third most common topography (8.9\%). The most common subtype was benign epithelial lesions, accounting for $30.43 \%$ of cases. There was a small number of cases, which limits comparison with other surveys. Malignant lesion was the most common subtype in Spraul $(46.4 \%)$ as in other studies..$^{1,15}$ Many surveys confine their studies to tumours of the orbit. Orbital tumour malignancy ranged from $36 \%$ to $63 \% .{ }^{16-18}$ Surveys concerning all space- occupying lesions reported $45 \%$ of malignant tumours in adults, ${ }^{19}$ and $22 \%$ to $57 \%$ of malignant tumours in children. ${ }^{19,20}$ In this study, only five cases were paediatric cases - all epithelial cysts. These results are similar to some studies ${ }^{21}$ concerning Mediterranean countries.

The number of enucleation specimens was reduced: only 13. Melanoma was the most common diagnosis. This survey is too small to be significantly compared with other studies, some of those with thousands of patients or with a different target population..$^{22-37}$ In the same way, our 
Table 2 - Frequency of specimens from conjunctiva

\begin{tabular}{|c|c|c|c|}
\hline Conjuntiva & Number & $\%$ & Mean age \\
\hline Miscellaneous lesions & 10 & $14.49 \%$ & 52.6 \\
\hline Hemorrhage & 1 & $10.00 \%$ & 84 \\
\hline Fibrosis & 1 & $10.00 \%$ & 28 \\
\hline Other & 8 & $80,00 \%$ & 51.75 \\
\hline Inflammation & 8 & $11.59 \%$ & 34.63 \\
\hline Inflammation, unspecific & 2 & $25.00 \%$ & 44 \\
\hline Chronic inflammation, unspecific & 3 & $37.50 \%$ & 26 \\
\hline Granulation tissue proliferation & 3 & $37.50 \%$ & 37 \\
\hline Degenerative lesions & 4 & $5.80 \%$ & 57.25 \\
\hline Pinguecula & 4 & $100.00 \%$ & 57.25 \\
\hline Benign epithelial tumours & 4 & $5.80 \%$ & 51.5 \\
\hline Epithelial cysts & 1 & $25.00 \%$ & 22 \\
\hline Squamous cell papilloma & 3 & $75.00 \%$ & 61.33 \\
\hline Precancerous epithelial lesions & 6 & $8.70 \%$ & 60 \\
\hline Actinic keratosis & 6 & $100.00 \%$ & 60 \\
\hline Malignant epithelial lesions & 7 & $10.14 \%$ & 72.43 \\
\hline Basal cell carcinoma & 1 & $14.29 \%$ & 74 \\
\hline Squamous cell carcinoma & 6 & $85.71 \%$ & 72.17 \\
\hline Melanocytic tumours & 25 & $36.23 \%$ & 35.76 \\
\hline Lentigo & 2 & $8.00 \%$ & 57.5 \\
\hline Juncional nevus & 1 & $4.00 \%$ & 29 \\
\hline Compound nevus & 15 & $60.00 \%$ & 24.93 \\
\hline Dermal nevus & 7 & $28.00 \%$ & 53.71 \\
\hline Vascular tumours & 2 & $2.90 \%$ & 16.5 \\
\hline Pyogenic granuloma & 1 & $50.00 \%$ & 30 \\
\hline Cavernous hemangioma & 1 & $50.00 \%$ & 3 \\
\hline Lymphoid tumours and tumour-like conditions & 2 & $2.90 \%$ & 34.5 \\
\hline Lymphoid hiperplasia & 1 & $50.00 \%$ & 14 \\
\hline \multicolumn{4}{|l|}{ Lymphoma } \\
\hline Marginal zone B-cell lymphoma & 1 & $50.00 \%$ & 55 \\
\hline Normal Tissue & 1 & $1.45 \%$ & 61 \\
\hline Total & 69 & & \\
\hline
\end{tabular}

experience regarding cornea, lacrimal gland and caruncula is almost insignificant. Only five specimens from cornea were collected, all following trauma events. The Department of Ophthalmology has no authorization for cornea transplantation. In Spraul's study, the cornea was the most common specimen, and its most frequent diagnoses were keratitis and bullous keratopathy. ${ }^{1}$ It was not possible to find studies similar to Spraul's. Some publications describe only indications for penetrating keratoplasty ${ }^{38-42}$ but we did not find any evidence of histological diagnosis (instead of clinical diagnosis) and percentages were different, with a higher prevalence of dystrophies. The lacrimal gland accounted for $1.2 \%$ of cases in this study, which is similar to the estimate of $1.4 \%$ from Spraul's study. ${ }^{1}$ Again, the study is too small for comparison with any reliable series. According to the literature, inflammatory specimens tend to be the most common $(25.0 \%-64.0 \%)$, followed by tumours $(12.3 \%-37.5 \%)$, lymphoid tumours $(9.2 \%-27.1 \%)$ and miscellaneous lesions $(6.0 \%-21.5 \%)^{1,43-45}$; the exception was Von Holstein's study, in which malignant tumours were the most frequent. ${ }^{46}$ Polito et al identified in his study that adenoid cystic carcinoma was the most common malignant tumour. ${ }^{44}$ Lastly, we had $0.8 \%$ cases of caruncula. In Spraul's study, the caruncula corresponded to $1.0 \%$ of specimens. ${ }^{1}$ In 2009, Levy et al published a review with his survey, comparing it to other similar seven studies; nevus ranged from $16.8 \%$ to $59.5 \%$; cysts from $5.1 \%$ to $34.6 \%$; and papilloma from $4.7 \%$ to $31.6 \% .{ }^{47}$

\section{CONCLUSION}

This study found that eyelid and conjuntiva were the most common specimens submitted to surgery and pathological 
Table 3 - Frequency of specimens from orbit

\begin{tabular}{|c|c|c|c|}
\hline Orbit & Number & $\%$ & Mean age \\
\hline Miscellaneous lesions & 4 & $17.39 \%$ & 53.75 \\
\hline Other & 4 & $75.00 \%$ & \\
\hline Inflammation & 3 & $13.04 \%$ & 38.67 \\
\hline Chronic inflammation, unspecific & 3 & $100.00 \%$ & \\
\hline Benign epithelial tumours & 7 & $30.43 \%$ & 13 \\
\hline Epithelial cysts & 7 & $100.00 \%$ & \\
\hline Lipomatous tumours & 2 & $8.70 \%$ & 62 \\
\hline Lipoma & 2 & $100.00 \%$ & \\
\hline Meningeal tumours & 1 & $4.35 \%$ & 59 \\
\hline Meningioma & 1 & $100.00 \%$ & \\
\hline Peripheral nerve sheath tumours & 1 & $4.35 \%$ & 58 \\
\hline Neurilemoma & 1 & $100.00 \%$ & \\
\hline Fibroblastic/myofibroblastic tumours & 1 & $4.35 \%$ & 62 \\
\hline Inflammatory myofibroblastic tumour & 1 & $100.00 \%$ & \\
\hline Lymphoid tumours and tumour-like conditions & 2 & $8.70 \%$ & 77 \\
\hline \multicolumn{4}{|l|}{ Lymphoma } \\
\hline Follicular lymphoma & 1 & $50.00 \%$ & 76 \\
\hline Marginal zone B-cell lymphoma & 1 & $50.00 \%$ & 78 \\
\hline Normal Tissue & 2 & $100.00 \%$ & 29 \\
\hline Total & 23 & & \\
\hline
\end{tabular}

Table 4 - Frequency of specimens from enucleation

\begin{tabular}{lccc}
\hline Enucleation & Number & $\%$ & Mean age \\
\hline Miscellaneous lesions $\quad$ 5 & $38.46 \%$ & 39.00 \\
$\quad$ Other & 5 & $100.00 \%$ & 60.86 \\
Melanoma & 8 & $61.54 \%$ & \\
Total & 13 & & \\
\hline
\end{tabular}

Table 5 - Frequency of specimens from cornea

\begin{tabular}{lccc}
\hline Cornea & Number & $\%$ & Mean age \\
\hline Miscellaneous lesions & $\mathbf{2}$ & $\mathbf{4 0 . 0 0 \%}$ & $\mathbf{4 8}$ \\
$\quad$ Other & 2 & $100.00 \%$ & $\mathbf{8 1}$ \\
Inflammation & $\mathbf{2 0 . 0 0 \%}$ & $\mathbf{4}$ & \\
$\quad$ Acute inflammation & 1 & $\mathbf{4 8 . 5}$ \\
Normal tissue & $\mathbf{2}$ & $\mathbf{4 0 . 0 0 \%}$ & \\
Total & $\mathbf{5}$ & & \\
\hline
\end{tabular}

Table 6 - Frequency of specimens from lacrimal gland

\begin{tabular}{lccc}
\hline Lacrimal gland & Number & $\%$ & Mean age \\
\hline Benign epithelial tumours & $\mathbf{2}$ & $\mathbf{6 6 . 6 7 \%}$ & $\mathbf{7 1 . 5}$ \\
$\quad$ Epithelial cysts & 2 & $100.00 \%$ & $\mathbf{8 2}$ \\
Lymphoid tumours and tumour-like conditions & $\mathbf{1}$ & $\mathbf{3 3 . 3 3 \%}$ & $\mathbf{1 0 0 . 0 0 \%}$ \\
$\quad$ Lymphoma & 1 & & \\
Total & $\mathbf{3}$ & & \\
\hline
\end{tabular}

characterization. The rates of corneal specimens and enucleation were specially low when compared to other centers around the world; the latter is because our center has no authorization for corneal transplantation; and also because there are Portuguese 'reference centres for ophthalmic oncology (Centro de Responsabilidade Integrada em Oftalmologia, Centro Hospitalar e Universitário de Coimbra, Coimbra, Portugal; IPO-Porto, 
Table 7 - Frequency of specimens from caruncula

\begin{tabular}{lccc}
\hline Caruncula & Number & $\%$ & Mean age \\
\hline Benign epithelial tumours & $\mathbf{1}$ & $\mathbf{5 0 . 0 0 \%}$ & $\mathbf{2 9}$ \\
$\quad$ Squamous cell papilloma & 1 & $100.00 \%$ & $\mathbf{5 9}$ \\
Melanocytic tumours & $\mathbf{1}$ & $\mathbf{5 0 . 0 0 \%}$ & $100.00 \%$ \\
$\quad$ Dermal nevus & 1 & & \\
Total & 2 & & \\
\hline
\end{tabular}

Porto, Portugal), where specialized teams provide care for this kind of diseases. Lastly, it can be concluded that the frequency of specimens is what's expected given the broad care that is intended to be provided by a department like this, with a catchment area of 1.2 million people, including both urban and non-urban areas.

This is the first publication in a PubMed indexed journal regarding the characterization of ophthalmic specimens in a Portuguese Department of Ophthalmology. It covers data from the beginning of activity and extends over more than 10 years, in order to get a significant overview of this matter. A literature review was also done and this is the first known review since Spraul's study, which was published almost 20 years ago.

\section{PROTECTION OF HUMANS AND ANIMALS}

The authors declare that the procedures were followed according to the regulations established by the Clinical Research and Ethics Committee and to the Helsinki Declaration of the World Medical Association.

\section{DATA CONFIDENTIALITY}

The authors declare having followed the protocols in use at their working center regarding patients' data publication.

\section{CONFLICTS OF INTEREST}

The authors reported no conflict of interest.

\section{FUNDING SOURCES}

This research received no specific grant from any funding agency in the public, commercial, or not-for-profit sectors.

University Hospital and literature review. Ann Pathol. 2012;32:170-6.

15. Kennedy RE. An evaluation of 820 orbital cases. Trans Am Ophthalmol Soc. 1984;82:134-55.

16. Domingo RE, Manganip LE, Castro RM. Tumors of the eye and ocular adnexa at the Philippine Eye Research Institute: a 10-year review. Clin Ophthalmol. 2015;9:1239-47.

17. Shields JA, Shields CL, Scartozzi R. Survey of 1264 patients with orbital tumors and simulating lesions: The 2002 Montgomery Lecture, part 1. Ophthalmology. 2004;111:997-1008.

18. Demirci H, Shields CL, Shields JA, Honavar SG, Mercado GJ, Tovilla JC. Orbital tumors in the older adult population. Ophthalmology. 2002;109:243-8

19. Johansen S, Heegaard S, Bøgeskov L, Prause JU. Orbital spaceoccupying lesions in Denmark 1974-1997. Acta Ophthalmol Scand. 2000;78:547-52

20. Bajaj MS, Pushker N, Chaturvedi A, Betharia SM, Kashyap S, Balasubramanya $\mathrm{R}$, et al. Orbital space-occupying lesions in Indian children. J Pediatr Ophthalmol Strabismus. 2007;44:106-11.

21. Bisulli F, Foschini MP, Dallera P, Gaist G. Expanding lesions of the orbit: Multicase review. Pathologica. 1997;89:256-63.

22. de Gottrau P, Holbach LM, Naumann GO. Clinicopathological review of 1146 enucleations (1980-1990). Br J Ophthalmol. 1994;78:260-5.

23. Günalp I, Gündüz K, Ozkan M. Causes of enucleation: a clinicopathological study. Eur J Ophthalmol. 1997;7:223-8.

24. Cheng GY, Li B, Li LQ, Gao F, Ren RJ, Xu XL, et al. Review of 1375 enucleations in the TongRen Eye Centre, Beijing. Eye. 2008;22:1404-9.

25. Kord Valeshabad A, Naseripour M, Asghari R, Parhizgar SH, Parhizgar SE, Taghvaei $M$, et al. Enucleation and evisceration: indications, complications and clinicopathological correlations. Int J Ophthalmol. 2014;7:677-80.

26. Mondal SK, Ghosh AK. Histopathological analysis of 150 enucleated eyes. Indian J Pathol Microbiol. 2007;50:11-4.

27. Setlur VJ, Parikh JG, Rao NA. Changing causes of enucleation over the past 60 years. Graefes Arch Clin Exp Ophthalmol. 2010;248:593-7.

28. Sengupta S, Krishnakumar S, Biswas J, Gopal L, Khetan V. Fifteen-year trends in indications for enucleation from a tertiary care center in South India. Indian J Ophthalmol. 2012;60:179-82.

29. Scat Y, Liotet S, Bellefqih S. Etiology of enucleations. Apropos of 3,246 
cases. J Fr Ophtalmol. 1996;19:242-7.

30. Tahri H, Benatya AD, Chefchaouni CM, El Bakkali M, Berraho A. Enucleations: epidemiologic investigation in Morocco. presentation of 183 cases. Bull Soc Belge Ophtalmol. 2004:31-4.

31. Huang S, Crawford JB, Porco T, Rutar T. Clinicopathologic review of pediatric enucleations during the last 50 years. J AAPOS. 2010;14:32833.

32. Epee E, Masanganise R. The rate of and indications for enucleations at Sekuru Kaguvi Eye Unit in Harare: a comparative analysis. Cent Afr J Med. 2003;49:13-5.

33. Vittorino M, Serrano F, Suárez F. Enucleation and evisceration: 370 cases review. Results and complications. Arch Soc Esp Oftalmol. 2007;82:495-9.

34. Bal A, Mohan $H$, Chabbra S, Sood S. Causes of enucleation in Northern India (1995-2005). Eur J Ophthalmol. 2007;17:638-41.

35. Hansen AB, Petersen C, Heegaard S, Prause JU. Review of 1028 bulbar eviscerations and enucleations. Changes in aetiology and frequency over a 20-year period. Acta Ophthalmol Scand. 1999;77:331-5.

36. Geirsdottir A, Agnarsson BA, Helgadottir G, Sigurdsson H. Enucleation in Iceland 1992-2004: study in a defined population. Acta Ophthalmol. 2014;92:121-5

37. Babar TF, Hussain M, Zaman M. Clinico-pathologic study of 70 enucleations. J Pak Med Assoc. 2009;59:612-4

38. Yu AL, Kaiser M, Schaumberger M, Messmer E, Kook D, Welge-Lussen $\mathrm{U}$. Perioperative and postoperative risk factors for corneal graft failure. Clin Ophthalmol. 2014;8:1641-7.
39. Al-Yousuf N, Mavrikakis I, Mavrikakis E, Daya SM. Penetrating keratoplasty: indications over a 10 year period. $\mathrm{Br} \mathrm{J}$ Ophthalmol. 2004;88:998-1001.

40. McClellan K, Lai T, Grigg J, Billson F. Penetrating keratoplasty in children: visual and graft outcome. Br J Ophthalmol. 2003;87:1212-4.

41. Vanathi M, Sharma N, Sinha R, Tandon R, Titiyal JS, Vajpayee RB. Indications and outcome of repeat penetrating keratoplasty in India. BMC Ophthalmol. 2005;5:26.

42. Lang SJ, Bischoff M, Böhringer D, Seitz B, Reinhard T. Analysis of the changes in keratoplasty indications and preferred techniques. PLoS One. 2014;9:e112696

43. Shields CL, Shields JA, Eagle RC, Rathmell JP. Clinicopathologic review of 142 cases of lacrimal gland lesions. Ophthalmology. 1989;96:431-5.

44. Polito $E$, Leccisotti $A$. Epithelial malignancies of the lacrimal gland: survival rates after extensive and conservative therapy. Ann Ophthalmol. 1993;25:422-6.

45. Eldesouky MA, Elbakary MA, Sabik S, Shareef MM. Lacrimal fossa lesions: a review of 146 cases in Egypt. Clin Ophthalmol. 2014;8:1603-

46. von Holstein SL, Therkildsen MH, Prause JU, Stenman G, Siersma VD, Heegaard S. Lacrimal gland lesions in Denmark between 1974 and 2007. Acta Ophthalmol. 2013;91:349-54.

47. Levy J, Ilsar M, Deckel Y, Maly A, Pe'er J. Lesions of the caruncle: a description of 42 cases and a review of the literature. Eye. 2009;23:100418. 